\title{
EL RETABLO MAYOR DEL CONVENTO DE SANTA ISABEL DE LOS REYES DE TOLEDO: NUEVAS APORTACIONES A LA OBRA DE JUAN BAUTISTA MONEGRO, ANDRÉS SÁNCHEZ, JUAN SÁNCHEZ DÁVILA Y PEDRO DE CISNEROS EL MOZO
}

\author{
POR \\ Herbert GonZÁLEZ ZyMLA* \\ Universidad Complutense de Madrid
}

\begin{abstract}
Las pruebas documentales aquí aportadas y el estudio de las formas artísticas, demuestran que el retablo mayor de Santa Isabel de los Reyes es una de las obras más sobresalientes de la escultura toledana del siglo XVI. Encargado antes de 1570, estaba concluido, como señala el epígrafe que preside el propio retablo, en el año 1572, siendo abadesa María de Guzmán. Ha permanecido como anónimo hasta la localización de dos órdenes de pago que lo documentan como obra del arquitecto y escultor Juan Bautista Monegro, del entallador Andrés Sánchez y de los pintores-doradores Juan Sánchez Dávila y Pedro de Cisneros el Mozo a cuyos respectivos catálogos debe incorporarse como obra destacada, especialmente en lo tocante al estudio de Juan Bautista Monegro, que fue el de mayor trascendencia de los cuatro. Desde el punto de vista formal y estilístico, sus relieves y esculturas se pueden relacionar con lo mejor del clasicismo de los Leoni.
\end{abstract}

Palabras claves: Santa Isabel de los Reyes; Toledo; Escultura; Siglo XVI; Juan Bautista Monegro; Andrés Sánchez; Juan Sánchez Dávila; Pedro de Cisneros el Mozo.

Documents studied here and the analysis of the work demonstrate that the main altarpiece of Santa Isabel de los Reyes is one of the most outstanding examples of Toledan 16th-century sculpture. Commissioned in 1570 , it was completed by 1572 , according to the inscription on the altarpiece, which until now has remained anonymous. The discovery of two payment orders demonstrate that it was created by the architect and sculptor Juan Bautista Monegro, the woodcarver Andrés Sánchez and the painter-gilders Juan Sánchez Dávila and Pedro de Cisneros el Mozo, to whose respective catalogues this work should be added, particularly that of Juan Bautista Monegro. From the formal and stylistic point of view, the reliefs and statues by Monegro can be related to the best classicism of the Leoni.

Key words: Santa Isabel de los Reyes; Toledo; Sculpture; 16 ${ }^{\text {th }}$ century; Juan Bautista Monegro; Andrés Sánchez; Juan Sánchez Dávila; Pedro de Cisneros el Mozo.

* Agradezco las fotografías del presente artículo a D. Roberto Alonso Moral y al Departamento de Arte del CSIC. 
El convento de Santa Isabel de Toledo ${ }^{1}$, indistintamente citado en los documentos como "Santa Isabel de los Reyes" y "Santa Isabel la Real", fue fundado en 1477 por María de Toledo $^{2}$, más conocida con el sobrenombre de Sor María la Pobre, hija de Pedro Suárez de Toledo y Juana de Guzmán, señores de Pinto, miembros de una familia noble emparentada con el linaje de los Duques de Alba, los Condes de Oropesa y los de Orgaz. María la Pobre era pariente de los Reyes Católicos a través de la bisabuela de Fernando el Católico, Inés de Ayala, y ello facilitó la recepción de un conjunto de casas-palacio que habían sido heredadas por Fernando en la colación de San Antolín ${ }^{3}$ y cedidas a Sor María el 27 de julio de 1480 para que fundara en ellas un monasterio. El Cardenal Mendoza ${ }^{4}$ entre 1483 y 1488 facilitó la fundación suprimiendo la parroquia de San Antolín ${ }^{5}$ para ceder su edificio mudéjar a fin de que las religiosas establecieran allí la iglesia conventual. A estos patrimonios se sumaron una serie de propiedades agropecuarias y urbanas que conformaron el primer dominio monástico ${ }^{6}$. En 1488 fue enterrada en el coro de monjas la princesa Isabel de Castilla, hija de los Reyes Católicos y reina de Portugal por su matrimonio con Manuel el Afortunado. Como las monjas concedieron la licencia para enterrar a la infanta, los Reyes Católicos beneficiaron al convento concediéndole un privilegio de 37.500 maravedíes de renta anual. Estos dineros sirvieron para financiar la transformación de las casas palaciales en convento y para reacondicionar la vieja iglesia de San Antolín. El Papa Alejandro VI (Rodrigo Borgia), en bula dada el 26 de junio de 1502, autorizó a las monjas a reparar, conservar y mantener los muros y la fábrica de la iglesia, otorgando, además, una serie de gracias e indulgencias que se celebrarían en ocasión de ciertas festividades religiosas.

A principios del siglo XVI debe datarse la transformación de la vieja iglesia parroquial de San Antolín, que conservaba hasta entonces su fábrica mudéjar del siglo XIII, con más o menos añadidos de los siglos XIV y XV. Se derribaron las naves central y sur de la parroquia y se unificaron (fig. 1). El templo quedó convertido en iglesia de una sola nave muy amplia y se rehizo la cabecera dentro del estilo tardo-gótico de principios del XVI, como si fuera una capilla ochavada, que, al exterior, deja visibles tres paños de muro, cubierta con bóveda de terceletes y combados con círculo en el polo cenital, formando una especie de rueda de ocho radios, que simboliza el dogma de la Santísima Trinidad ${ }^{7}$. La capilla mayor fue edificada en piedra irregular, montada con argamasa de cal hidráulica, materiales relativamente pobres, pero ignífugos, que son característicos de la tradición arquitectónica toledana. Sólo se tallaron en buena piedra, bien escuadrada, los sillares esquinados, las ménsulas y las nervaduras de la bóveda que dibujan una flor de cuatro pétalos. Se ignora quién pudo ser el arquitecto que diseñó la transformación, pero la presencia de decoración a base de perlas de Ávila en uno de los contrafuertes permite pensar que las obras son inmediatas a la concesión de los permisos pontificios. Debía estar terminada en 1553, porque en esa fecha el albañil Alexo Gómez (único que se ha podido documentar) se

1 Porres Martín Cleto, J., "El convento de Santa Isabel de los Reyes”, en Anales Toledanos, Toledo, 1973, n. ${ }^{\circ} 6$. Martínez Caviró, Balbina, Conventos de Toledo, Madrid, 1990, pp. 208-229.

2 Tamayo de Vargas, T., Vida de Doña María de Toledo, señora de Pinto, Toledo, 1616. Heredero, Encarnación, Vida de la Excelentísima Señora y Venerable Madre Doña María Suárez de Toledo, llamada por su humildad Sor María la Pobre, fundadora y primera abadesa del Real Monasterio de Santa Isabel de Toledo, Toledo, 1914.

${ }^{3}$ AHN [Archivo Histórico Nacional]: Clero, Carp. 3129: doc. 16.

${ }^{4}$ AHN: Clero, Carp. 3130: doc. 1.

5 AHN: Clero, Carp. 3130: doc. 2: 28-XI-1485, doc. 3: 18-I-1488, doc. 4: 1-IX-1488, doc. 5: 3-X-1488, doc. 6: 27-X-1488, doc. 7: 27-X-1488 (con una nota de 1577).

${ }^{6}$ AMSIRT [Archivo del Monasterio de Santa Isabel de los Reyes de Toledo]: Libro Becerro de los bienes, censos, etc. del Convento de Santa Isabel de los Reyes.

${ }^{7}$ ReAu, Louis, Iconografía del arte cristiano. Iconografía de la Biblia. Antiguo Testamento, Barcelona, 1999, tomo I, vol. 1, traducción de Daniel Alcoba, pp. 40-41. 


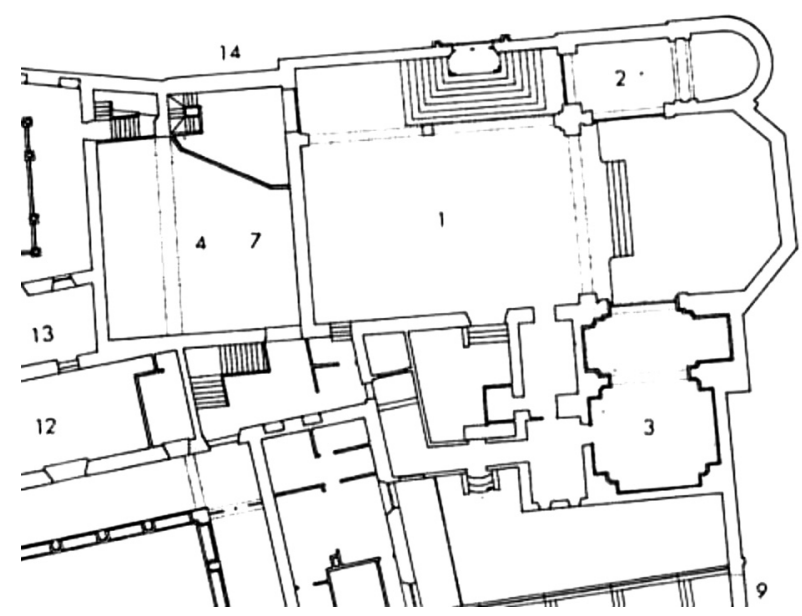

Fig. 1. Planta de la iglesia de Santa Isabel de los Reyes Toledo.

obligó a "jaharrar y blanquear los muros y bóveda y a levantar las gradas y altares del presbiterio" $"$.

El retablo mayor de Santa Isabel de los Reyes es una obra monumental, de estilo plenamente renacentista e influjo clásico italiano, claramente filiado con el sentir solemne de los Leoni ${ }^{9}$ (especialmente a Pompeo). Tiene una inscripción en letra capital romana sobre fondo dorado, en la base de la predela, de lado a lado, en la que reza: "ESTE RETABLO MANDÓ HACER LA ILUSTRE SEÑORA MARÍA DE GUZMÁN, ABADESA, EL PRIMER AÑO DE SU ABACIADO. ACABOSE $A \tilde{N} O D E 1572 " 10$. La datación vuelve a repetirse dentro de una cartela ovalada, en letra negra sobre fondo blanco, en el segundo cuerpo del retablo, bajo la fórmula "AÑN" "1572" (fig. 2).

Por razones obvias, la construcción del retablo hubo de ser posterior a 1553 y anterior a 1572, año en que se afirma que estaba acabada. Se ignora la fecha exacta en que María de Guzmán fue elegida abadesa de Santa Isabel de los Reyes, pero, en el epígrafe del retablo Mayor se dice claramente que se acabó la obra en 1572. En unos documentos notariales relacionados con el arriendo de los pastos de la dehesa de la Palomilla a Lucas Padilla en la cantidad de 17.100 maravedíes, fechados entre el día 22 de mayo de 1570 y el 17 de julio de 1570, se citan como abadesa a Juana de Toledo ${ }^{11}$, como vicaria a María Yáñez y como monjas discretas a Inés Méndez y a Catalina de las Peñas ${ }^{12}$. En algún momento entre julio de 1570 y agosto de 1571 María de Guzmán fue elegida abadesa de Santa Isabel pues figura como tal, firmando la carta de dote de la monja Jerónima García Yánez, fechada el 8 de agosto de 1571, más conocida como Jerónima de la Asunción y Jerónima de la Fuente ${ }^{13}$, ante el notario Fernando de Santa María ${ }^{14}$. Junto a ella se citan como vicaria a María Vázquez y como discretas a Mencía del Niño (o de Miño),

8 Cerro Malagón, Rafael del, Sainz, María Jesús, Delgado Valero, Clara, Pérez Higuera, Teresa y Franco Mata, Ángela, Arquitecturas de Toledo. Del Romano al Gótico, Toledo, 1991, p. 181.

9 Proske, Beatrice Gilman, Pompeo Leoni work in marble and alabaster in relation to Spanish sculpture, New York, 1956.

10 Martínez Claviró, Balbina, op. cit., 1990, p. 216.

11 No ha de ser confundida ésta con la homónima abadesa que gobernó Santa Isabel desde 1606.

${ }^{12}$ AHPT [Archivo Histórico Provincial de Toledo]: Sección de Protocolos Notariales. Notario Alonso García Yáñez, P-1174, fol. DCCVII, DCCIX y CCLXXIX.

${ }^{13}$ Sor Jerónima es conocida por el retrato que Velázquez pintó en 1620 (Museo del Prado).

${ }^{14}$ AMSIRT: Escritura de la dote de Doña Jerónima Yánez y en religión llamada Sor Jerónima de la Assumpción para el Monasterio de Santa Isabel de esta ciudad de Toledo. Doc. Notarial sin signatura. 


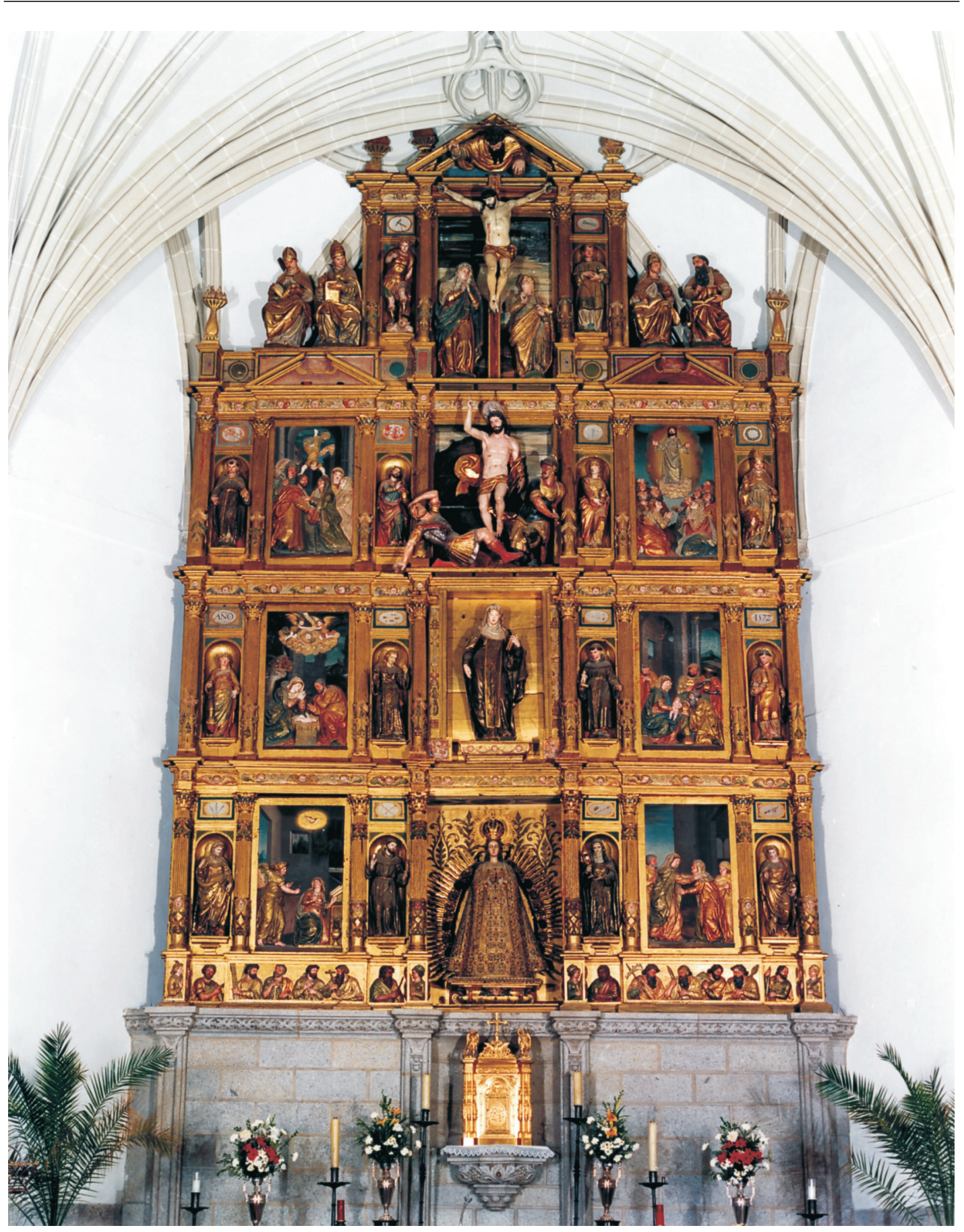

Fig. 2. Retablo Mayor de la Iglesia de Santa Isabel de los Reyes. 
Catalina de las Peñas, Ana Padilla, Isabel de Ayala y Francisca de Belén, tía de la joven monja Jerónima de la Asunción.

Una de las claves que facilitan el estudio del retablo mayor de Santa Isabel de los Reyes debe buscarse en las relaciones familiares de la discreta Francisca de Belén y su sobrina, Jerónima, con otros miembros laicos de la familia. Sor Jerónima de la Fuente nació en el seno de una familia toledana bastante acomodada, que vivía en la calle de los Letrados, el día 9 de mayo de $1555^{15}$, su padre, el jurista Pedro García Yánez, era miembro de la nobleza toledana y procurador del convento en las causas comunes que tenía pendientes en la audiencia de Toledo. Pedro García Yánez era hijo de un notario homónimo, activo en Toledo entre 1524 y 1541. Según Ana de Cristo, Jerónima "tuvo un abuelo de Salamanca y una abuela de Yepes"16, de modo que hemos de pensar que los García Yáñez se habían formado en Salamanca. La madre de Jerónima, Catalina de la Fuente, también natural de Toledo, procedía de una familia de judíos conversos ${ }^{17}$. Jerónima fue la tercera de las cuatro hijas. Sus dos hermanas mayores se llamaban María y Petronila ${ }^{18}$, y su hermana menor Mariana. María y Mariana murieron doncellas, mientras que Petronila García de la Fuente, llegó a adulta y contrajo matrimonio con Pedro Laso Coello de la Vega, Señor de Montalvo. Pedro García Yáñez tuvo un hermano y dos hermanas: La primera de ellas se llamaba Francisca García Yáñez, que ingresó en el convento de Santa Isabel de los Reyes como Francisca de Belén, monja que firma como discreta en la carta de profesión de su sobrina y, andados los años, llegó a ser abadesa del convento como demuestran varios actos de fe pública fechados el 18 de abril de $1582^{19}$ y el 18 de marzo de $1583^{20}$. La otra hermana se llamaba Inés García Yáñez, también fue monja en Santa Isabel, citada como Inés de Santa Ana, que alcanzó el cargo de maestra de novicias y vicaria en el tiempo en que su hermana era abadesa. El hermano se llamaba Alonso García Yánez, uno de los notarios activos en Toledo durante la segunda mitad del siglo XVI de quien se conocen protocolos notariales fechados entre los años 1554 y 1584, fecha de su muerte.

Aprovechando la relación familiar que el notario tenía con tres de las monjas (sus dos hermanas y su sobrina, que juntas debían formar una especie de oligarquía conventual), Alonso García Yáñez protocolizó muchos de los negocios y asuntos que afectaban al convento. La mayor parte de los contratos de arriendo que las monjas firmaron en las décadas de 1560 y 1570 con quienes explotaban sus tierras a cambio de una renta, se hicieron ante el escribano Alonso García Yánez. Entre los numerosos documentos que permiten reconstruir la vida económica del monasterio se conservan algunos de interés histórico artístico como dos de las tres cartas de pago a los artistas que hicieron el retablo mayor del convento ${ }^{21}$.

La primera de estas cartas está datada en Toledo el 15 de abril de 1572. En ella, las monjas de Santa Isabel de los Reyes, a la cabeza de las cuales está la abadesa, María de Guzmán, la vicaria, María Vázquez, y las discretas Ana de Padilla, Catalina de las Peñas, Isabel de Ayala, Francisca de Belén y Mencía de Miño, abonan la cantidad "de quinientos ducados en razón de a once reales

${ }^{15}$ Letona, Bartolomé de, Perfecta religiosa. Contiene tres Libros. Libro I: De la vida de la Madre Gerónima de la Asunçión de la Orden de Nuestra Madre Santa Clara..., 1662, Libro I, p. 2. RuAno DE SANTA Teresa, Pedro, La Venerable Madre Sor Jerónima de la Asunción. Fundadora del monasterio de Santa Clara de Manila y la primera mujer misionera en Filipinas, Madrid, 1993, p. 14.

16 AMSIRT: Ms. CRISTO, Ana de, Historia de Nuestra Santa Madre Jerónima de la Asunción, Cap. I. RuANo SANTA Teresa, Pedro, op. cit., 1993, p. 10.

17 MartíneZ Caviró, Balbina, op. cit., 1990, p. 224.

${ }^{18}$ Letona, Bartolomé de, op. cit., 1662, Libro I, p. 3.

19 AHPT: Sección de Protocolos Notariales. Notario Alonso García Yánez, P-1781, fol. CLXXVII-CLXXVIII y CCI.

20 AHPT: Sección de Protocolos Notariales. Notario Alonso García Yánez, P-1782.

21 AHPT: Sección de Protocolos Notariales. Notario Alonso García Yánez, P-1776. 
cada ducado, los cuales son para en cuenta de los mil cinquenta ducados que dicho monasterio nos está obligado a pagar del Retablo que nos obligamos a hacer para el dicho monasterio con los cuales están recibidos mil e trece ducados de a once reales cada ducado"22. Pocos meses después, en el mismo libro notarial, en fecha del 10 de julio de 1572, se documenta una segunda carta de pago en la que se abonan "cincuenta y siete ducados de los cuales, con los treinta y siete ducados que restaban de pagar por cumplimiento a los mil cincuenta ducados [...] porque nos obligamos a hacer Retablo para el dicho monasterio, que está ya hecho, los veinte ducados son por razón que nos los han dado de las demasías que hicimos en la custodia del dicho Retablo, que son por todo mil e setenta ducados los que tenemos recibidos por el dicho Retablo"23.

Los dos libramientos se hacen a favor de un equipo formado por cuatro artistas, dos escultores, Andrés Sánchez y Juan Bautista Monegro, y dos pintores, Pedro de Cisneros el Mozo y Juan Sánchez Dávila. Los cuatro firman ambas cartas de pago y "se dieron por contentos" 24 (fig. 3). Un facsímil de la firma de Juan Bautista Monegro fue publicado por García Rey en el año $1932^{25}$ que no coincide en los rasgos esenciales con la firma que nosotros hemos encontrado. Las posibles objeciones que pudieran ponerse al respecto de su identificación se solventan teniendo en cuenta que la firma de la carta de pago que nosotros hemos localizado, corresponde a los primeros años de su trabajo, mientras que la que publica García Rey corresponde a su plena madurez y, cualquier grafólogo sabe que la firma varía sensiblemente a lo largo del tiempo. Desgraciadamente, el contenido del protocolo no identifica exactamente el retablo como "retablo mayor", pero cabe suponer que se trata de él porque el epígrafe del retablo mayor de Santa Isabel confirma que se terminó en 1572 y a este año corresponden ambas cartas de pago. Resulta perfectamente lógico y coherente que, acabada la obra, se hiciera el pago de la misma. En principio, la documentación eclesiástica referente a los encargos y pagos de obras en los conventos especifica muy cuidadosamente, cuando se trata de retablos menores, los abonos de dinero "por pago del retablo de San...", pero, cuando se hacen obras en el retablo mayor se firman diciendo "se pagó por el Retablo" sin necesidad de ninguna otra aclaración, haciendo uso de la " $R$ " mayúscula en la palabra "Retablo" para manifestar que se trata del mayor y no de otro cualquiera y es así como aparece en ambos documentos. Al ser las cartas de pago que certifican el cumplimiento del contrato no necesitan mayor aclaración.

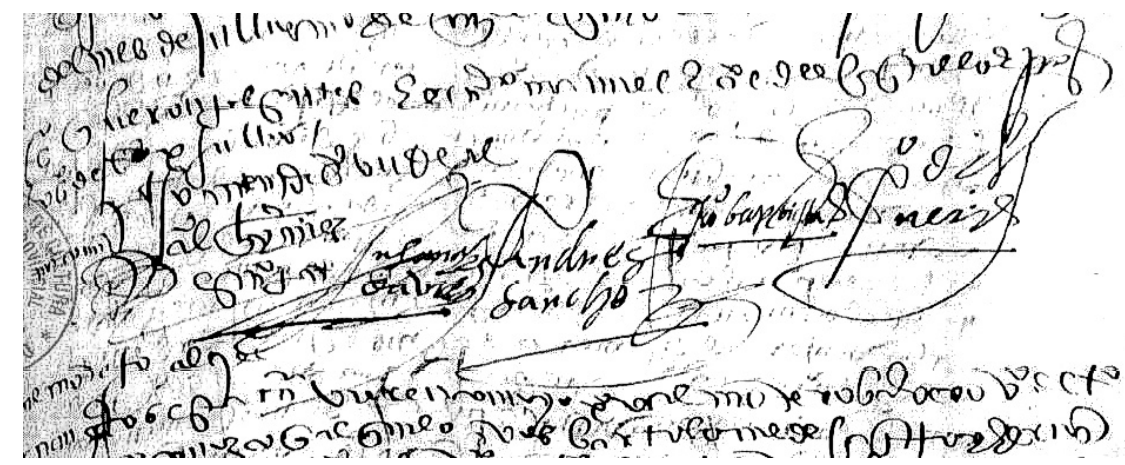

Fig. 3. Firmas de los autores del retablo en órdenes de pago fechadas en 1572: Andrés Sánchez, Juan Bautista Monegro, Pedro de Cisneros el Mozo y Juan Sánchez Dávila.

22 Ibidem, P-1776, fol. CIIv y CIIIr.

23 Ibidem, P-1776, fol. CCCXXIIIv y CCCXXIVr.

24 Ibidem, P-1776, fol. CIIIr.

${ }_{25}$ García Rey, V., "Juan Bautista Monegro, escultor y arquitecto”, en Boletín de la Sociedad Española de Excursiones, 1932, p. 114. 
Ambas cartas permiten deducir la existencia de un contrato de obras que, de momento, no se ha podido localizar, pero que cabe suponer se firmó en el año inmediatamente anterior, pues el epígrafe dice que el retablo fue mandado hacer por la abadesa María de Guzmán en el primer año de su abadiato, quizá como primera gran obra por ella ordenada. Si la obra se terminó en 1572 y se hizo en el primer año de abadiato de María de Guzmán, debió contratarse, necesariamente, en fecha incierta del año 1570 o 1571 . Si tal fuera el caso, sería sorprendente la rapidez con que se terminaron tales obras, que, por su tamaño y calidad debieron llevar más tiempo. Es seguro que en este contrato se estipularían las condiciones del encargo, los materiales y los tiempos en que la obra debía estar terminada y montada, así como la forma en que debía pagarse. La tasación total de la obra en el contrato inicial era de 1050 ducados de a 11 reales cada uno, de los cuales, en el primer pago, para comenzar la obra, se dio a los artistas la cantidad de 513 ducados en carta de pago que no conocemos y que debió fecharse antes de 1571 e inmediatamente después de firmado el contrato, para la compra de los materiales y el comienzo efectivo de las obras. En el segundo pago, que es el que se ha transcrito, se dio a los artistas la cantidad de 500 ducados por haber terminado la obra y, por último, en un tercer pago, se les dio la cantidad de 57 ducados, de la cual, 37 ducados eran para cubrir el precio estipulado en su origen y los 20 restantes, se dieron a manera de compensación por la demasía de gasto que habían hecho los artistas en el dorado del sagrario y expositor de la custodia. El precio final, como queda dicho, ascendió a 1070 ducados, 20 más que los establecidos en el contrato inicial, precio muy adecuado al tamaño y complejidad del retablo a tenor de otros contratos de la época que se conocen.

La adenda de dinero por la demasía de gasto que se hizo en el sagrario tiene mucha importancia a la hora de confirmar que se trata del retablo mayor de Santa Isabel de los Reyes ya que en los conventos franciscanos hay un único sagrario situado (a no ser que exista privilegio para ser expuesto en capilla concreta, que no es el caso en el convento de Santa Isabel) en el altar mayor. Como la carta de pago dice que "los veinte ducados son por razón que nos los han dado de las demasías que hicimos en la custodia del dicho Retablo" 26 , queda bastante claro que estamos ante el retablo mayor sin que exista posibilidad de duda.

Desde el punto de vista artístico, es un retablo de estructura arquitectónica clasicista, ejecutado en madera dorada y policromada, que se organiza sobre predela o banco, formando cuatro pisos (tres superpuestos y ático de coronamiento) y tres calles separadas entre sí por cuatro entrecalles a base de columnas de orden compuesto (de fuerte inspiración clásica romana, todas con idéntico basamento, fuste y capitel, es decir, no hay superposición de órdenes). Los entablamentos son quebrados en ángulo recto para crear juegos de luz y de sombra que refuercen el efecto monumental de la arquitectura y se corona el conjunto con un ático de frontón recto y flameros llameantes. Pese a la indudable calidad clasicista de los relieves y la profusión de ornamentos vegetales, veneras, candelieri, etc., domina un fuerte sentido arquitectónico y estructural. Esa claridad estructural es habitual en los retablos españoles del s. XVI a partir de 1562, directísimamente vinculados con la irrupción de los modelos de Palladio y Vignola.

Desde el punto de vista iconográfico el retablo es sumamente complejo, pero se integra perfectamente en los esquemas narrativos y compositivos habituales en el pleno renacimiento español siendo los distintos relieves que lo componen de muy desigual calidad lo que evidencia, seguramente, la diferencia de manos que intervienen en su ejecución. Su lectura se hace de abajo a arriba y de izquierda a derecha en los cuerpos laterales y de abajo a arriba en el cuerpo central, coronado, como es lo habitual, por un solemne calvario en el ático o espina. El esquema general organiza una manifestatio, una narratio y una testificatio.

La manifestatio es, como el propio nombre indica, la manifestación doctrinal de uno de los grandes dogmas de la iglesia católica, es decir, la presentación ante el fiel de uno o varios

${ }^{26}$ Ibidem, P-01776, fol. CCCXXIVr. 
principios fundamentales de la fe que se quieren poner ante los ojos y la mente de los hombres como principio rector de su conducta y sus creencias (no se ha de olvidar que el valor que los hombres daban a las imágenes en la Edad Moderna era siempre de tipo didáctico y propagandístico). El dogma más habitualmente representado es la Santísima Trinidad que ocupa los lugares más altos y preeminentes del retablo. En la capilla mayor de Santa Isabel de los Reyes el dogma de la Santísima Trinidad está presente de dos formas diferentes: La primera manifestatio Trinitatis es la ya citada rueda de ocho radios de la bóveda de terceletes y combados. La segunda manifestatio Trinitatis está presente en el ático y es de tipo figurativo. En ella se muestra a la persona del Hijo a través de la imagen de Cristo Crucificado en el monte Calvario, flanqueado por su madre la Virgen María y San Juan Evangelista, en el momento en que la Virgen se convierte en madre de la humanidad. El Cristo crucificado es una imagen serena, de anatomías clasicistas, llena de corrección académica, cuya concepción anatómica está directamente inspirada en el conocimiento de los desnudos de la estatuaria clásica grecolatina, conocida en el Toledo del siglo XVI a través de las colecciones artísticas de la nobleza y el clero y, sobre todo, a través de estampas y dibujos. El canon de las figuras es más bien alargado y la belleza del desnudo queda visible en el leve desplazamiento del paño de pureza que tapa el sexo de Cristo, ladeado para dejar visible la diartrosis inguinal. Formalmente, el calvario puede ser relacionado con un grupo, perfectamente documentado como obra de Pompeo Leoni, procedente del convento de San Diego de Valladolid, que se conserva en el Museo Nacional de Escultura, datado en época posterior, en 1605, pero casi idéntico al que corona el retablo de Santa Isabel ${ }^{27}$. Sobre el calvario, que muestra bien la influencia del arte de los Leoni en la obra de Juan Bautista Monegro, está representado Dios Padre como un enérgico anciano de barba abundante y pelo blanco (de claro influjo Miguelangelesco), que emerge del interior del frontón recto para bendecir a la humanidad con la mano derecha, al tiempo que, con la izquierda, sostiene el orbe, rebasando el marco arquitectónico del frontón. El fuego de luz del Espíritu Santo está representado a través de los flameros llameantes que coronan el retablo y la abundancia de dorados (fig. 4).

La narratio consiste en la narración progresiva, por medio de imágenes de más o menos compleja lectura, de la Historia Sagrada, bien del Antiguo Testamento o del Nuevo, organizadas de modo que, a través de las imágenes, se proporcione al fiel un discurso perfectamente legible y didáctico en el que se muestran los hitos fundamentales de la Historia Sagrada. En el retablo de Santa Isabel de los Reyes, la narratio se concentra en un recorrido que se lee, de izquierda a derecha y de abajo a arriba, a través de los relieves de las tres calles pero, principalmente, de las laterales. Como es habitual en los conventos franciscanos del siglo XVI está dedicado a la vida de Cristo, mostrado como hijo de Dios que se hizo hombre para redimir a la humanidad de sus pecados a través del sacrificio de la cruz y como dador de resurrección y vida eterna (de ahí que la calle central concentre la doble escena de la muerte y resurrección como partes esenciales de la narratio).

Leyendo los relieves ordenadamente, en el piso inferior, en ambas calles laterales, se muestra la Anunciación y la Visitación (figs. 5 y 6). En el primer relieve se muestra la encarnación de Jesucristo en el vientre de la Virgen. El ángel se presenta ante la Virgen María que, arrodillada frente a un atril con el libro de profecías, recibe la gracia del Espíritu Santo y concibe en su seno al hijo de Dios. El Espíritu Santo está representado en forma de paloma rodeada de rayos de luz materializados. El segundo relieve muestra el abrazo de la Virgen y su prima, Santa Isabel, ambas embarazadas, en cuyos vientres se gestan y saltan de gozo San Juan Bautista, que anunciará la venida del Salvador, y el niño Jesús, el Mesías. Ambos relieves son una representación del reconocimiento de la naturaleza Divina de Cristo antes de su nacimiento ya que está represen-

27 Arias MartíneZ, Manuel y LunA, Luis, Museo Nacional de Escultura, Madrid, 1995, p, 62. 


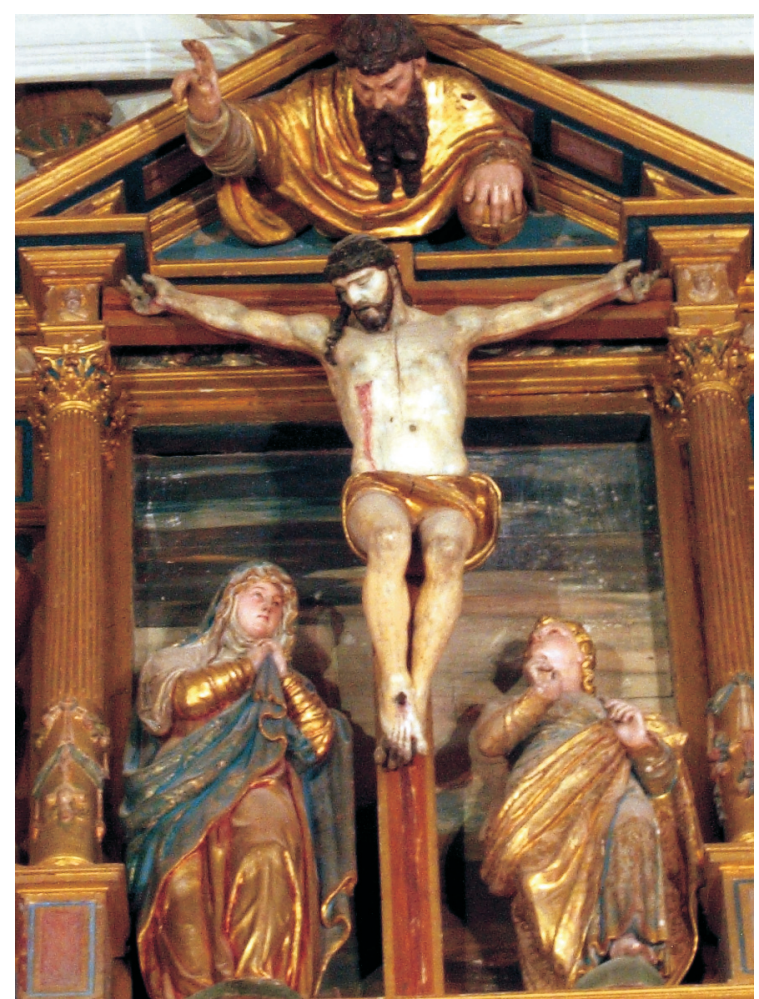

Fig. 4. Calvario. Ático del retablo.

tado como hijo de Dios y como Mesías. Todos los relieves, al igual que otras muchas esculturas tienen un tratamiento de paños muy elegante, que acentúa el volumen y sentido del movimiento de todas las esculturas, cayendo en vertical y dibujando "s", nuevamente de raigambre italiana, clasicista y enraizada con los Leoni.

En el segundo piso hay otros dos relieves en las calles laterales que prosiguen la narratio con la representación del nacimiento del niño Jesús y la adoración de los Reyes Magos. El nacimiento de Cristo muestra al niño Jesús envuelto en pañales y colocado sobre un pesebre, situado en la parte central del relieve, en el momento en que recibe la adoración de sus padres terrenales, la Virgen María y San José, arrodillados y representados de perfil (en claro signo de erudición anticuaria pues se trata de un perfil numismático) con las manos juntas, y de los ángeles en el cielo, sobre nubes, que le cantan continuas alabanzas. El relieve dedicado a la adoración de los Reyes Magos muestra a la Virgen sentada con el niño en el regazo recibiendo los presentes que reconocen la triple naturaleza de Cristo: oro como a Rey, incienso como a Dios y mirra como a hombre, al tiempo que muestran la universalidad del mensaje de Cristo, pues cada uno de los reyes procedía de una región del mundo conocida (África, Europa y Asia) y cada uno tenía una edad (uno era joven, otro era maduro y otro anciano). Por tanto, los relieves del segundo piso muestran la universalidad del mensaje de Cristo y la necesaria adoración del Hijo de Dios.

El tercer piso está ocupado por tres escenas que muestran leídas de izquierda a derecha, el abrazo ante la puerta dorada, la resurrección de Cristo y la ascensión de Cristo a los cielos. El primero de los relieves del tercer piso resulta inconexo con el discurso narrativo general, pues se trata de una representación del abrazo de San Joaquín y Santa Ana ante la Puerta Dorada 


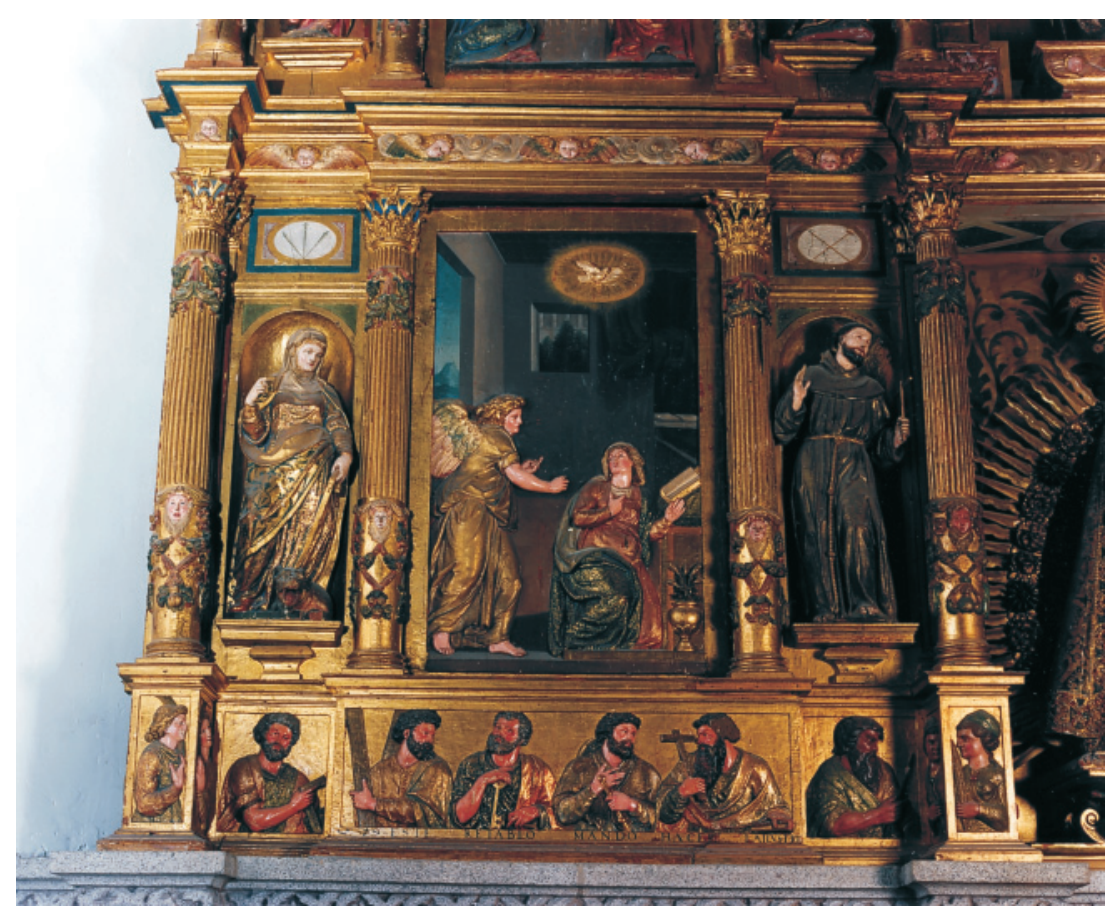

Fig. 5. La Anunciación. Retablo. Santa Isabel de los Reyes.

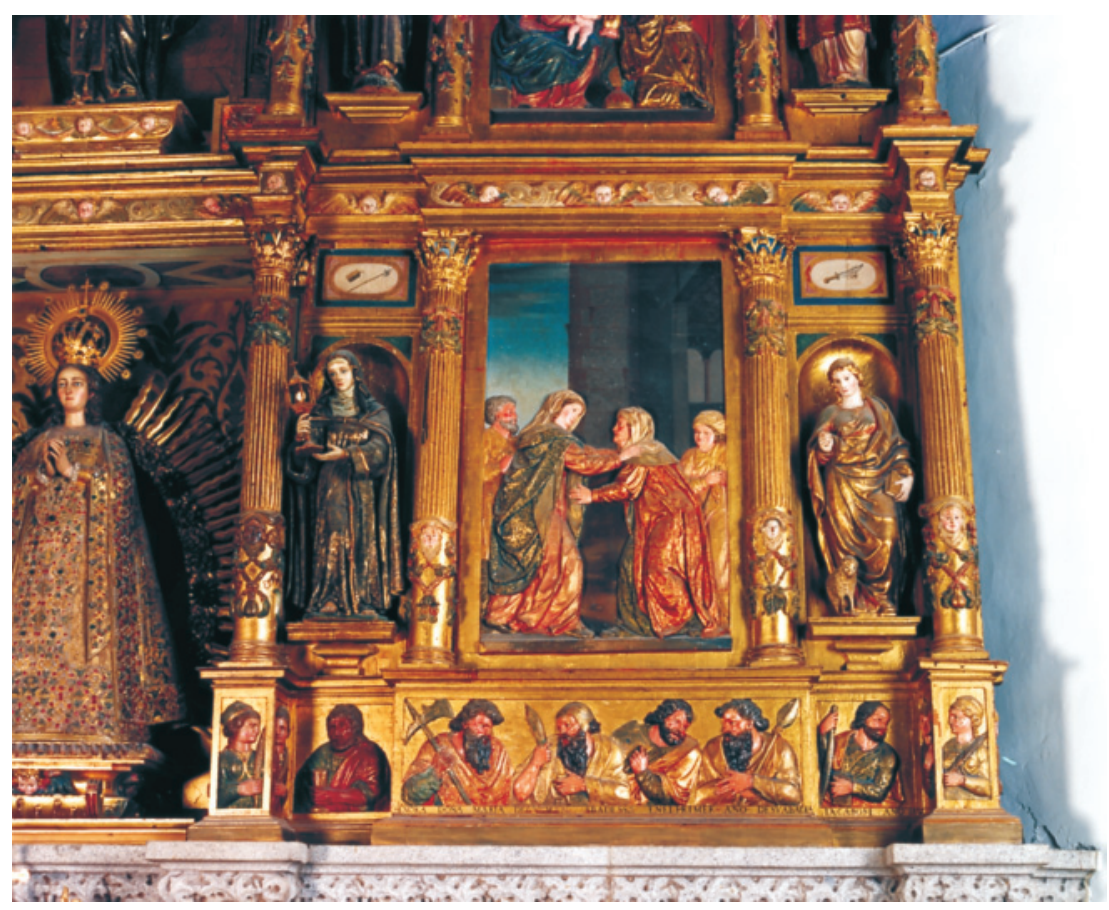

Fig. 6. La Visitación. Con el epígrafe de la abadesa María de Guzmán y la fecha de 1572 a la derecha. 


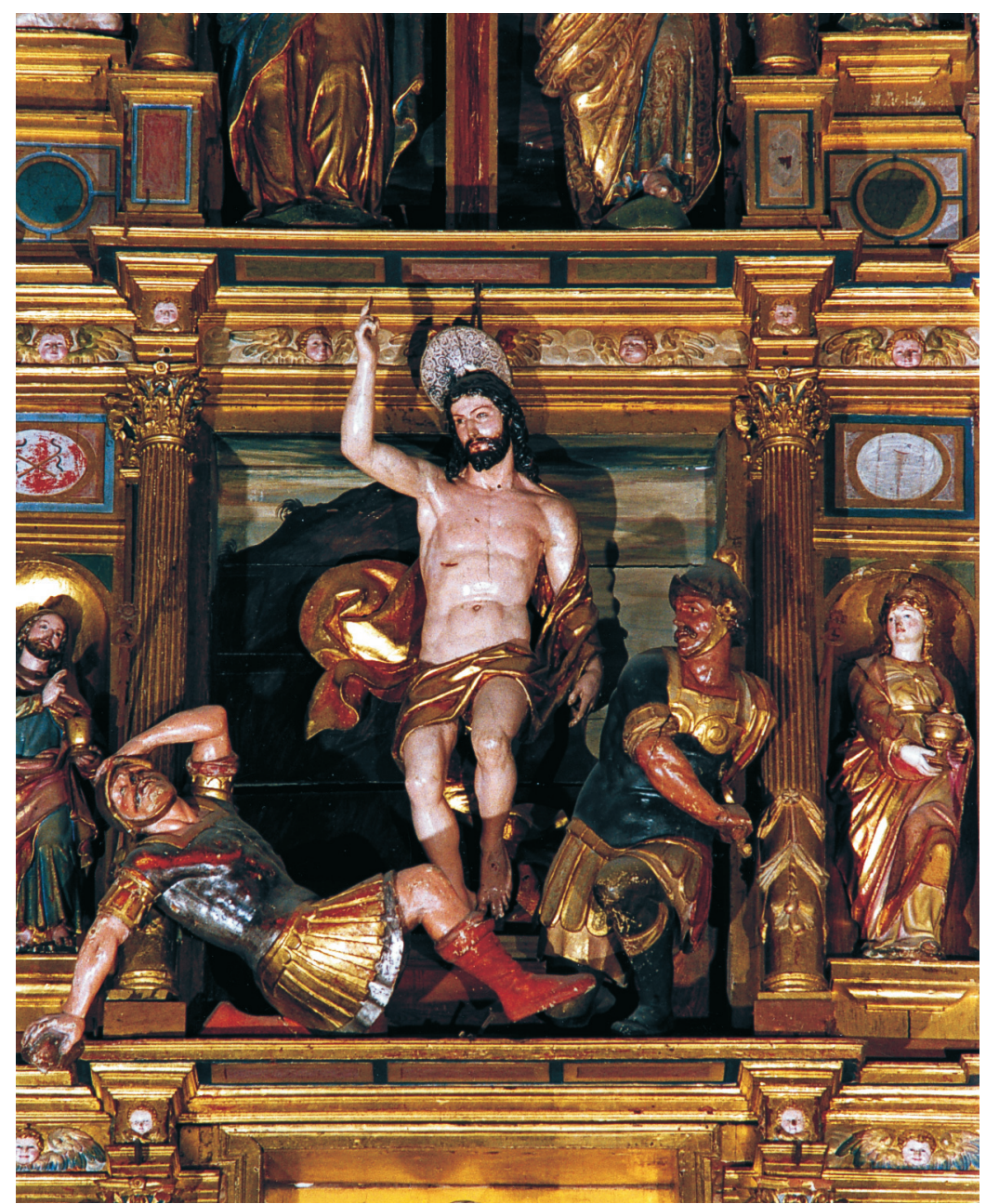

Fig. 7. La Resurrección de Cristo.

con un ángel que les une sus cabezas con las manos. Esta iconografía tiene mucho que ver con las formas antiguas de representación de la Inmaculada Concepción, pues muestra el piadoso reencuentro de los padres de la Virgen y su concepción, pese a la ancianidad de Santa Ana, exenta de la mancha del pecado original (que es un pecado de desobediencia) como si fuera una segunda Eva que, por una gracia especialmente concedida por Dios, podrá concebir en su seno a su único hijo exento de la mancha del pecado. Si la narratio fuera coherente, este relieve debería ser el primero del primer piso, pues, cronológicamente, es un hecho anterior a la anunciación y a la visitación. Puede que su emplazamiento tenga alguna relación con el hecho de que los franciscanos fueron, en el siglo XVI, afamados defensores de la postura teológica inmaculadista y, quizá, con el hecho de que el patrón de la diócesis de Toledo, San Ildefonso, fuera también un acérrimo defensor de la exención de la mancha del pecado original en la Virgen. Sólo por esta razón podría justificarse una posición alta y preeminente dentro del retablo, pero incoherente desde el punto de vista narrativo. Debe advertirse, eso sí, que en los retablos del siglo XVI los relieves suelen emparejarse de modo que la anunciación aparece 
formando pareja con la visitación y el nacimiento con la adoración, de modo que el retablo de Santa Isabel resultaría perfectamente canónico respecto a los modelos icónicos de ordenación de espacios y temáticas.

Los otros dos relieves están en relación con el ya explicado Calvario del ático. Son la Resurrección de Cristo, que es un grupo escultórico muy efectista y volumétrico, que rebasa el marco arquitectónico del retablo. Capta el momento en que Cristo triunfa sobre la muerte mostrando a los soldados romanos dormidos y caídos a los pies del Santo Sepulcro, en posiciones forzadas que también rebasan el marco arquitectónico (fig. 7). La composición está llena de dinamismo y movimiento, la figura de Jesucristo es italianizante y de clarísima inspiración en los desnudos clásicos del siglo IV a. de C. de corte praxitélico para Cristo y de corte policlético, más musculoso, para los soldados dormidos. El último de los relieves es una representación de la ascensión de Cristo en presencia de los apóstoles, imagen que simboliza la definitiva vuelta del Hijo al Padre y que cierra la narratio dedicada a la vida, muerte y resurrección de Cristo.

La testificatio, como del propio nombre puede colegirse, es la representación de los apóstoles, los santos y las santas, que, a través de sus experiencias, dan testimonio de que todo lo allí expresado (manifestatio y narratio) es correcto y, por tanto, dan fe e indican acción y efecto de testificar. De todas las imágenes presentes en el retablo, la más importante es una escultura de bulto redondo y aspecto fusiforme, muy noble y de muy hermosas proporciones, que representa a Santa Isabel de Hungría ${ }^{28}$ (1207-1231), titular del convento, vestida con el hábito oscuro, llevando la regla de Santa Clara en la mano izquierda y la derecha pegada al cuerpo para no romper la forma ovalada, considerada por los artistas del pleno renacimiento como la más perfecta de cuantas se podían emplear en el arte de la escultura. Se trata de la imagen más importante del retablo ya que ocupa su cuerpo central y su calle central. Es significativo advertir que se ha prescindido de relatar en la narratio alguna parte de la vida de Santa Isabel de Hungría, patrona del monasterio, que, en realidad, ha sido representada como protectora del monasterio y como santa titular en una suerte de testificatio que prescinde de cualquier tipo de elemento narrativo en aras de una mayor solemnidad figurativa, como si sólo interesase mostrar a la santa como imagen noble del ideal monástico de la monja-abadesa perfecta e inalterable que cumple rigurosamente la regla franciscana (fig. 8).

En las hornacinas de las entrecalles, que son en forma de arco de medio punto (lo que contrasta con el carácter arquitrabado de la arquitectura del retablo), se representaron catorce santos, todos ellos de bulto redondo, en los que dominan, en el cuerpo inferior, las imágenes de San Francisco mostrando los estigmas de las manos y Santa Clara con la custodia en la mano (fig. 9). Ambos estaban a ambos lados del espacio que antiguamente había ocupado el graderío de la predela, el ostensorio y el sagrario. Otros Santos representados son Santa Rosita de Viterbo, San Lorenzo con la parrilla, San Esteban protomártir llevando el canto rodado en las manos, Santa Margarita con el dragón encadenado a sus pies, y un bellísimo San Miguel Arcángel vencedor de Satanás, en forzado contraposto (fig. 10). Dentro de óvalos esparcidos por todo el retablo están representadas las arma Christi.

Todo el retablo se asienta sobre un banco o predela rectangular que acoge un apostolado completo, en el que cada uno de los doce apóstoles está figurado en bajo relieve, de medio cuerpo y en actitud dialogante. Cada apóstol es reconocible gracias a los atributos que lleva en las manos.

Los remates de las calles laterales, a la altura del ático, están coronados con las imágenes de los Santos Padres de la Iglesia, San Ambrosio, San Gregorio, San Jerónimo y San Agustín, sabios que fundamentan los principios del cristianismo latino, representados en posición sedente

28 REAU, Louis, Iconografía del arte cristiano. Iconografía de los santos de la G a la O, Barcelona, 2001, tomo II, vol. 4, traducción de Daniel Alcoba, pp. 122-126. 


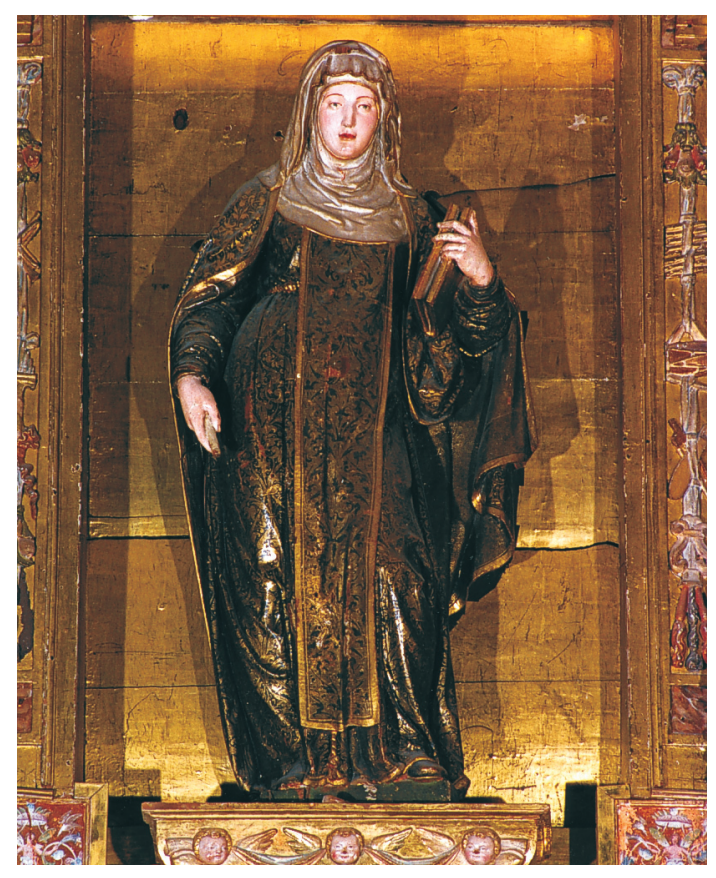

Fig. 8. Santa Isabel de Hungría.

y noblemente vestidos con ricas telas, mitras y capelos según su dignidad, cuyas posiciones y formas recuerdan en algo al Moisés de Miguel Ángel. Por último, recortados sobre la pared, flameros.

Desde el punto de vista técnico, la talla es bastante noble y fina pero desigual en función de las partes que ocupan las estatuas dentro del retablo. El equipo de artistas que hizo la obra combinó varias técnicas en función del emplazamiento de cada escultura. La calle central alberga las estatuas de bulto redondo y las de mejor calidad, sobrepuestas a un fondo liso y dorado para dar la sensación de ser altorrelieves. Su mayor volumen las hace resaltar frente a las restantes y, por su aspecto, son de mucha mejor calidad y factura, pues su sentido del orden y la belleza están directísimamente relacionados con el arte antiguo, a lo que se ha de añadir una riqueza notable en el tratamiento de los pliegues de los vestidos para resaltar los volúmenes. Si bien la imagen de Santa Isabel se ciñe al ideal manierista de la escultura fusiforme y el calvario se ciñe perfectamente al marco arquitectónico del ático, la resurrección de Cristo y el Dios Padre rebasan el marco arquitectónico y dan una sensación de mayor vitalidad y movimiento que supera la ley renacentista de adaptación al marco y anuncia un creciente interés por el movimiento y el naturalismo. En cambio, los relieves de las calles laterales son más convencionales en lo iconográfico y lo compositivo (es posible que traduzcan al relieve determinadas estampas italianas o flamencas del XVI) y tienen sólo volumen de medio relieves que se ciñen, perfectamente sometidos, al marco arquitectónico y reducen las composiciones a grupos de tres o cuatro figuras en aras de un mayor equilibrio compositivo y claridad expositiva de la narratio, concentrando el interés escultórico en los gestos, paños y posición de las manos. La predela, en cambio, se ejecutó a base de bajorrelieves y las hornacinas de las entre calles acogen estatuas de bulto redondo. Estas estatuitas son de muy desigual calidad, en principio, casi ninguna rebasa el marco y son mejores las que están en el primer cuerpo. Las más elegantes y cuidadas en la talla son, con diferencia, las imágenes de los patrones de la orden: San Francisco y Santa Clara. Los coronamientos, en cambio, son estatuas exentas recortadas sobre la pared. La policromía, el dorado y el estofado, disimulan las 


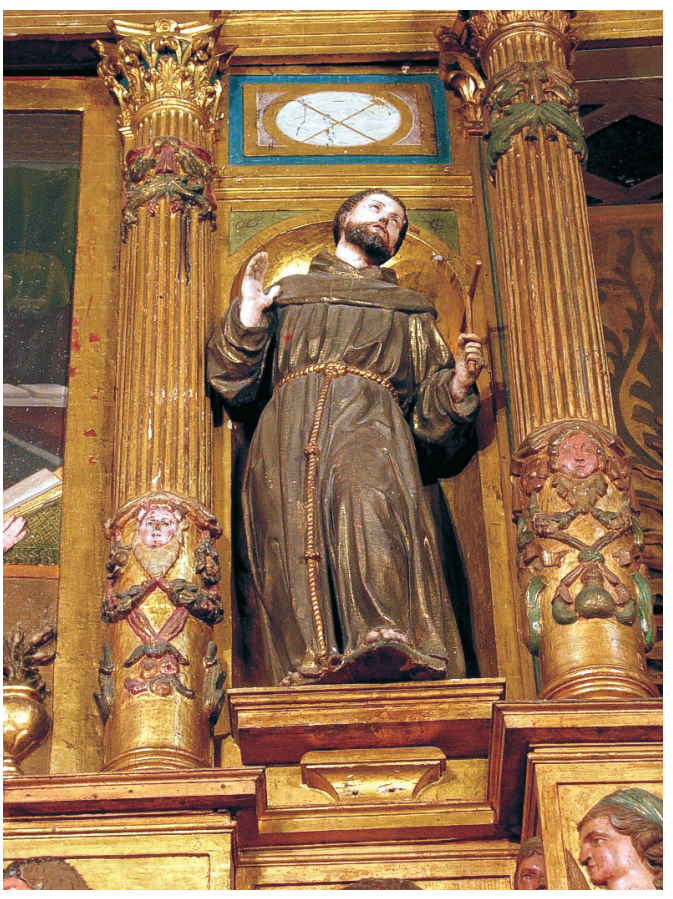

Fig. 9. San Francisco.

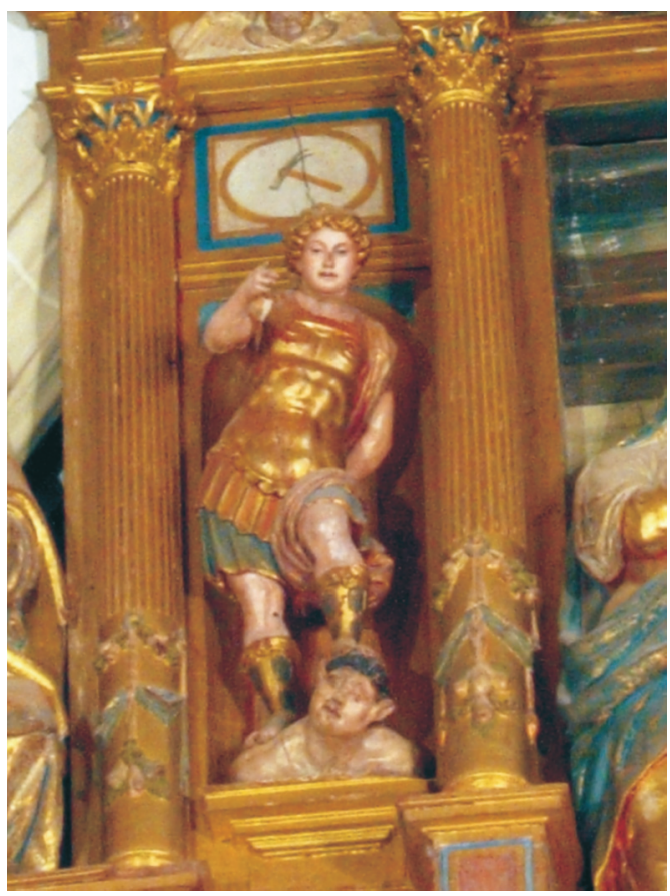

Fig. 10. San Miguel.

posibles diferencias de calidad en la talla y dan perfecta unidad al retablo, que, examinado en su conjunto, es uno de los más importantes dentro del panorama toledano del siglo XVI.

Hasta el hallazgo de las dos cartas de pago que acabamos de dar a conocer, siempre se había clasificado este retablo como obra anónima datada en 1572, dentro del estilo renacentista y rotundamente indocumentada. Generalmente, los autores que han escrito sobre este retablo han obviado la autoría y se han limitado a constatar la fecha de ejecución del epígrafe ${ }^{29}$ señalando su marcado carácter clásico. Los artistas que se citan en las dos cartas de pago son algunos de los más importantes del Toledo del siglo XVI. Desde el punto de vista formal, el estilo del retablo encaja perfectamente con las obras conocidas y documentadas de los dos escultores y los dos pintores.

Juan Bautista Monegro es el artista más importante de los cuatro que trabajaron en el retablo de Santa Isabel y, seguramente, fue el responsable de los elementos más significativos del retablo, entre ellos, de su arquitectura. Juan Bautista Monegro, a quien siempre se le asocia con lo mejor del arte toledano del $\mathrm{XVI}^{30}$, debió nacer en 1531, pero se duda el lugar exacto, pues unos afirman que vio la luz en Madrid $^{31}$, mientras que otros (los mejor documentados), dicen que nació en Toledo e, incluso, algunos dicen que era natural de Monegro (municipio santanderino del Valle de Yuso), nacido entre los años 1545 y $1550^{32}$. Lo cierto es que, pese a que siempre se le ha tenido como toledano, en opinión de García Rey, nació en Monegro hacia 1550, hijo de Luis Gómez y

\footnotetext{
${ }^{29}$ Martínez CAVIRó, Balbina, op. cit., 1990.

30 VV.AA. Pérez Sánchez, Alfonso E., El Toledo del Greco, Toledo, 1982, Cat. Exp. Hospital Tavera, p. 100.

31 CEÁn Bermúdez, Juan Agustín, Diccionario histórico de los más ilustres profesores de las Bellas Artes en España, Madrid, 1800, reed. 1965, tomo III, p. 167. Siguiendo opinión del Padre Sigüenza.

32 García ReY, V., op. cit., 1932, p. 114.
} 
Elena Sánchez de Monegro, naturales él de Ciruelos y ella de Toledo, pues en una información que se hizo en 1608 se dice que entonces tenía 58 años y se afirma, taxativamente, que era natural de Monegro. En cambio, en otra información del 3 de enero de 1615, Monegro, ante el notario Juan de Soria, dice que tenía más de 78 años, lo que nos llevaría a datar su alumbramiento entre los años 1545 y $1546^{33}$. Algunos citan que se formó con su supuesto padre, Álvaro Monegro, que era uno de los arquitectos activos en el Toledo del siglo XVI, pero, a la luz de los documentos dados a conocer por García Rey, el dato es disparatado. Ha de suponerse que se formó con su propia familia en el arte de la cantería, oficio habitual en el área cántabra. Monegro fue arquitecto y escultor ${ }^{34}$ y, si bien no llegó a viajar a Italia (por más que el Padre Andrés Jiménez y Palomino lo afirmen), su familiaridad con los Leoni ${ }^{35}$ hizo que dominase en su obra un estilo italianizante y plenamente renacentista, gracias al cual recibió muchos encargos oficiales en tiempos de Felipe II, en la década de 1580, entre ellos los cuatro evangelistas del templete que hay en el Patio de Evangelistas del Monasterio de El Escorial y los seis reyes (Josafat, Exequías, David, Salomón, Manasés y Josías) ${ }^{36}$ de la fachada principal de la basílica del mismo monasterio. Su estilo se ajusta a esculpir figuras de volúmenes monumentales y fusiformes, de siluetas bastante cerradas sobre sí mismas; con un tratamiento de los paños que añade aparatosidad, sensación de movimiento y teatralidad, buscando un creciente colorismo y contraste, acentuado con el propio volumen de las ropas que generan cejas de sombra. Ceán Bermúdez dice que "las esculturas de Monegro son notables por la exactitud de dibujo y proporciones, por la sencillez de las actitudes, por las bellas y grandiosas formas, por la nobleza de sus caracteres y por los excelentes

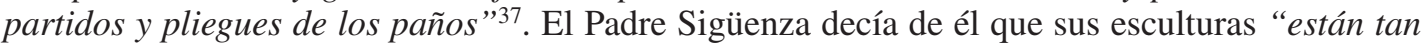
bien acabadas que se pueden comparar con lo bueno de la antigüedad". Palomino también alabó su estilo ponderándolo con los grandes maestros del clasicismo griego. Al objeto del estudio del retablo de Santa Isabel de los Reyes interesan, sobre todo, las primeras realizaciones artísticas de Monegro, es decir, aquellas que hizo en su etapa de aprendizaje y primera madurez (piénsese que esculpe el retablo de Santa Isabel de los Reyes cuando tiene entre 20 y 30 años) en el mismo año 1572 en que Palomino y Llaguno le sitúan trabajando en El Escorial. Entre estas obras deben destacarse algunos relieves esculpidos en piedra para varias de las puertas de la muralla y puentes de Toledo y algunas esculturas en piedra que hizo para las puertas de la Catedral Primada y, sobre todo, el diseño del retablo de Santo Domingo el Antiguo de Toledo ${ }^{38}$, en el que la armadura y los trabajos escultóricos son obra suya ${ }^{39}$, finalizada en 1580 , y sirven de acogida a algunas de las pinturas más sobresalientes del Greco. En 1579 hizo el retablo para el Monasterio de Santa Clara la Real de Toledo ${ }^{40}$. Precisamente, es con la arquitectura clasicista de estos retablos con la que se relacionan los órdenes corintios, hornacinas y tipos de entablamento quebrado que se observan en el retablo de Santa Isabel de los Reyes. El propio convento de Santa Isabel conserva en la capilla de la encarnación un magnífico retablo contratado en 1582, para la capilla fundada por Aldonza de Toledo y Meneses, cuya talla y arquitectura es obra de Monegro. Después de haber trabajado Monegro en las obras de El Escorial, regresó a Toledo, inaugurándose su segunda etapa

Ibidem, 1932, pp. 111-112.

34 García ReY, V., op. cit., 1932, pp. 22-38 y 124-145; 1934, pp. 202-223 y 1935, pp. 53-72. AzCÁrate, José María de, Escultura del siglo XVI, Ars Hispaniae, XIII, Madrid, 1958. MARÍAs, Fernando, La arquitectura del renacimiento en Toledo. 1541-1631, Toledo, 1983-1986.

35 Proske, B. G., op. cit., 1956.

36 ANDRÉs, Gregorio de, Inventario de documentos sobre la construcción y ornato del Monasterio del Escorial existente en el Archivo de su Real Biblioteca, Madrid, 1972.

37 Cé́n BermúdeZ, Juan Agustín, op. cit., 1965, p. 171.

38 Marías Franco, Fernando, El Greco, Madrid, 1991, p. 13.

39 García Rey, V., op. cit., 1932, pp. 22-38.

${ }^{40}$ Ibidem, pp. 30-31. 
toledana, más italianizante, más vinculada a la obra de Leoni y también más manierista, a la que pertenecen obras como el sepulcro del inquisidor Soto, el del canónigo Alonso de Rojas, el del Conde de Barajas y, posiblemente el de Francisco Eraso y Mariana de Peralta en Mohernando (Guadalajara). Fue en época avanzada de su vida, el 29 de diciembre de 1606, cuando, nombrado arquitecto de la Catedral de Toledo, construyó la capilla de la Virgen del Sagrario (1616) y el Ochavo. También se vinculan a él trabajos como los de la Iglesia de las Bernardas de Alcalá de Henares, en donde trabaja Juan Gómez de Mora, el convento de monjas clarisas de Jaén y la capilla y retablo de la Concepción de la Guardia. Aunque el edículo central del retablo de Santa Isabel no se ha conservado, Monegro fue un verdadero especialista en construir edículos para sagrarios de retablo mayor, formulando soluciones sencillas pero estructuralmente bien integradas en los conjuntos arquitectónicos. La relación de Monegro con el convento de Santa Isabel afecta también a la vida privada. El 19 de septiembre de 1601 su esposa, Catalina de Salcedo, imposibilitada, hizo testamento ante el escribano público Gabriel de Morales, donde dispuso que su cuerpo fuera sepultado en el ábside de San Antolín de la Iglesia de Santa Isabel de los Reyes, en la sepultura comprada que le pareciera a sus albaceas agregando que "su voluntad era que si al dicho su marido le pareciera fundar su capilla en otra iglesia o monasterio de Toledo, lo había de poder hacer a su voluntad, y alli ha de ser enterrado su cuerpo, y en el entretanto, depositado en San Antolín"41. Catalina murió el 14 de marzo de 1620, según registro del libro de difuntos de la parroquia de San Lorenzo. Monegro, viendo el final de su vida, solicitó permiso al consejo de la Gobernación del Arzobispado para que le diesen en propiedad dos aposentos de la sacristía de la iglesia parroquial de San Lorenzo, junto al altar mayor, para edificar en ellos una capilla dedicada a San Blas en la que poder disponer su sepultura y la de su esposa dotándola con 4.000 maravedíes de renta. El 20 de noviembre de 1620 dispuso Monegro su testamento ${ }^{42}$ y, en codicilo añadido ocho días después, dejó dispuesto cómo debía terminarse la capilla y el traslado del cadáver de su esposa desde Santa Isabel a San Lorenzo. Murió en Toledo el 16 de febrero de 1621 a la muy avanzada edad de 90 años.

Los artistas que se encargaron de policromar el retablo han sido objeto de estudio en una reciente monografía escrita por Isabel Mateo Gómez y Amelia López Yarto ${ }^{43}$. Pedro de Cisneros es miembro de una importante familia de pintores toledanos activos en la capital castellano manchega en el siglo XVI de los que conocemos nombre y actividad de cinco pintores distintos con este mismo apellido: Cristóbal de Cisneros (hermano de Pedro el Viejo documentado entre 1540 y 1570) ${ }^{44}$, Melchor de Cisneros (hijo de Pablo documentado entre 1571 y 1606) ${ }^{45}$, Pablo de Cisneros (sobrino de Pedro documentado entre 1570 y 1606) ${ }^{46}$, Pedro de Cisneros el Viejo (muerto en 1546) ${ }^{47}$ y Pedro de Cisneros el Joven o el Mozo (documentado entre 1546 y1591) ${ }^{48}$. El pintor que se encargó de la policromía del retablo de Santa Isabel de los Reyes ha de ser, necesariamente, Pedro de Cisneros el Mozo, porque para la fecha en que se ejecutó el retablo, 1572, Pedro de Cisneros el Viejo ya estaba muerto. Consta en el testamento que Pedro de Cisneros el Viejo hizo ante el notario Juan Sánchez Canales, el 16 de octubre de 1546, que fue su heredero universal y su único hijo, natural, reconocido como tal y aún menor de edad ${ }^{49}$. Es de

${ }^{41}$ García ReY, V., op. cit., 1931, p. 123.

42 Ibidem, pp. 124-125.

43 Mateo Gómez, Isabel y LóPez Yarto Elizalde, Amelia, Pintura Toledana de la segunda mitad del siglo XVI, Madrid, 2003.

44 Ibidem, p. 136.

45 Ibidem, p. 137.

46 Ibidem, pp. 137-140

47 Ibidem, pp. 140-141.

48 Ibidem, pp. 141-146.

49 AHPT. Notario Juan Sánchez de Canales, prot. 1310, fol. 1. 
suponer que se debió formar junto a alguno de los Cisneros que eran parientes suyos. Su actividad artística se documenta a partir de 1555 ininterrumpidamente hasta su muerte y, en varias ocasiones, vinculado a la orden franciscana, pues en 1564 consta que había hecho el retablo de talla y pintura del coro del convento de monjas de Santa Clara ${ }^{50}$. Es seguro que esta actividad es la que le abrió la puerta para trabajar en Santa Isabel. Es bien conocida la actividad de Pedro de Cisneros el Mozo como dorador y pintor de imaginería y, consecuentemente, su trabajo aparece asociado al de otros escultores. Es de particular importancia señalar que coincide con Monegro en algunos encargos, pues, según Ceán Bermúdez, "los Cisneros doraron y estofaron los retablos de la iglesia de las monjas bernardas de Toledo, llamadas de Santo Domingo el Antiguo en los

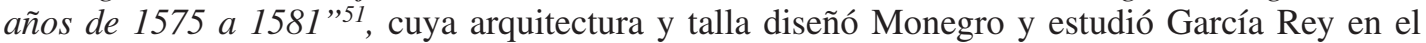
año 1932, sin poder dar fecha exacta a la obra ${ }^{52}$. Consta que en 1584 había contratado con Pedro de Cisneros el Mozo la construcción del retablo del Val de Santo Domingo, en el que Sánchez Dávila debía pintar seis tablas ${ }^{53}$ y ello indica, necesariamente, que se asociaban para ejecutar juntos determinados encargos.

Juan Sánchez Dávila ha sido un artista casi desconocido hasta ahora, de quien consta solamente su actividad entre 1561 y $1587^{54}$. Estaba avecindado en la parroquia de San Bartolomé de Sonsoles, junto al convento de Santa Isabel de los Reyes y, por ello, debía ser persona familiar al convento ${ }^{55}$. La asociación de Sánchez Dávila con los Cisneros se prolongó durante mucho tiempo pues, además de lo ya dicho respecto a su trabajo junto a Cisneros, consta que en 1584 fue nombrado tasador por Pedro y Pablo de Cisneros y por los entalladores de Villanueva de los Infantes Juan Ruiz de Elvira y Luis de Vellorino, del retablo de la Iglesia de Manzanares el Real ${ }^{56}$. Al año siguiente, en 1585 dio poder, junto a Pedro de Cisneros a favor de Pablo de Cisneros a propósito del cobro del retablo mayor de la iglesia del Val de Santo Domingo ${ }^{57}$ y en 1600 aparece como tasador con Diego de Aguilar el Mozo y con Pablo de Cisneros en relación con el retablo de los Mínimos que habían hecho Luis de Carvajal, Toribio González y Blas de Prado ${ }^{58}$.

De Andrés Sánchez sabemos poca cosa, apenas consta como entallador que trabaja ocasionalmente junto a alguno de los Cisneros con quienes debió asociarse para conseguir encargos de relativa importancia. Sólo se sabe que hizo el entallado de madera del cirio pascual de la Iglesia de San Cristóbal en 1547 y que Cristóbal de Cisneros hizo la policromía ${ }^{59}$.

Consecuentemente, estamos ante un equipo de artistas que trabajan juntos en obras patrocinadas o encargadas por los riquísimos conventos toledanos, todos ellos con intensas relaciones con los conventos franciscanos.

Fecha de recepción: 25-VII-2006

Fecha de aceptación: 15-I-2007

\footnotetext{
50 AHPT. Notario Juan Sánchez de Canales, prot. 1523, fol. 371.

51 CeÁn Bermúdez, Juan Agustín, op. cit., 1965, tomo I, p. 335.

52 García ReY, V., op. cit., 1932, pp. 22-38 y 124-145.

53 AHPT. Notario Juan Sánchez de Canales, prot. 1592, fol. 161.

54 Mateo Gómez, Isabel y López Yarto Elizalde, Amelia, op. cit., 2003, pp. 270-272.

55 AHPT. Notario Juan Sánchez de Canales, prot. 1577, fol. 1328.

56 AHPT. Notario Juan Sánchez de Canales, prot. 1589, fol. 431.

57 AHPT. Notario Juan Sánchez de Canales, prot. 1595, fol. 29.

58 AHPT. Notario Blas Hurtado, prot. 2233, fol. 330.

59 Ramírez de ARellano, 1920, p. 58.
} 